\title{
Correction to: Endothelial actions of atrial natriuretic peptide prevent pulmonary hypertension in mice
}

\author{
Franziska Werner ${ }^{1} \cdot$ Baktybek Kojonazarov $^{2,3} \cdot$ Birgit Gaßner $^{1} \cdot$ Marco Abeßer $^{1} \cdot$ Kai Schuh $^{1} \cdot$ Katharina Völker $^{1}$. \\ Hideo A. Baba ${ }^{4} \cdot$ Bhola K. Dahal $^{2,3} \cdot$ Ralph T. Schermuly ${ }^{2,3} \cdot$ Michaela Kuhn $^{1}$
}

Published online: 28 February 2022

(c) The Author(s) 2022

\section{Correction to: Basic Res Cardiol (2016) 111:22 \\ https://doi.org/10.1007/s00395-016-0541-x}

When this article was initially published, two of the illustrative pictures in Fig. 7 had been duplicated from Fig. 4. This mistake does not affect the results and conclusions. The figure should have appeared as shown below.

The original article can be found online at https://doi.org/10.1007/ s00395-016-0541-x.

Michaela Kuhn

michaela.kuhn@mail.uni-wuerzburg.de

1 Physiologisches Institut der Universität Würzburg, Röntgenring 9, 97070 Würzburg, Germany

2 Department of Internal Medicine, University of Gießen and Marburg Lung Center (UGMLC), Justus-Liebig University Gießen, Giessen, Germany

3 German Center for Lung Research, Heidelberg, Germany

4 Institute of Pathology, University Hospital of Essen, University of Duisburg-Essen, Essen, Germany 
A

$$
\operatorname{RVSP}(\mathrm{mm} \mathrm{Hg})
$$
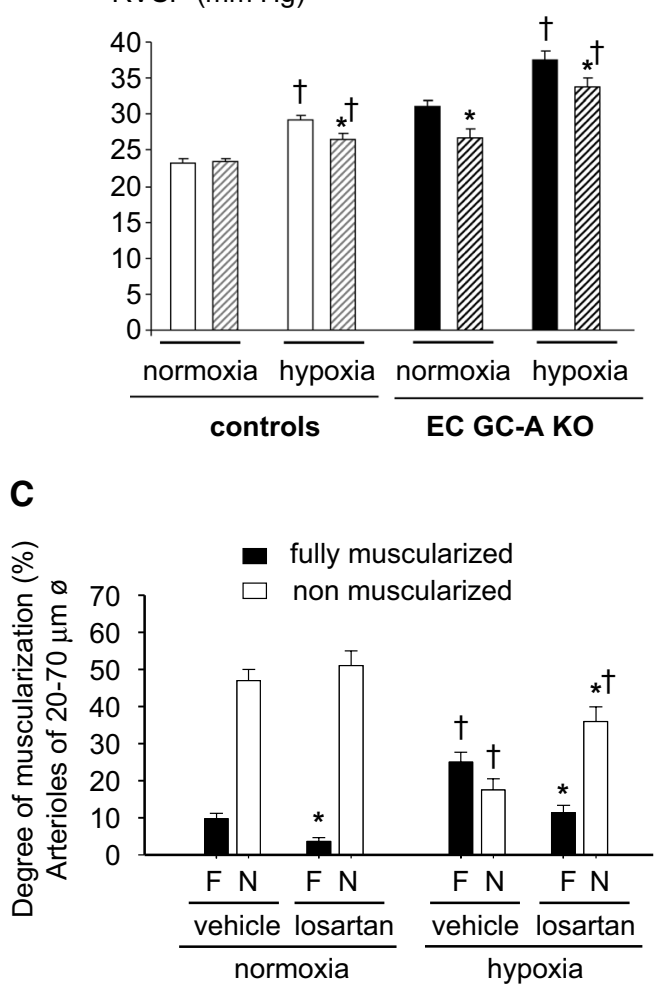

B

$\mathrm{RV}$ weight / tibia length $(\mathrm{mg} / \mathrm{cm})$

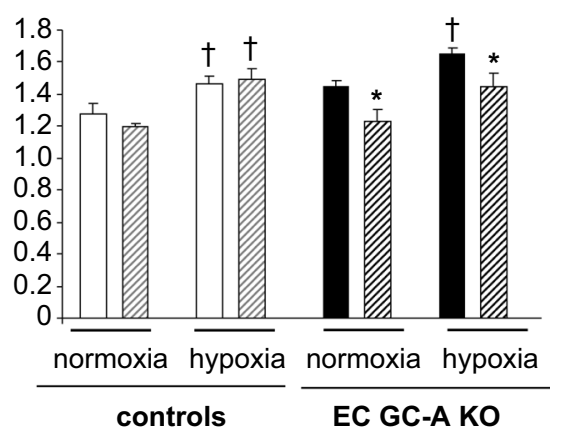

D
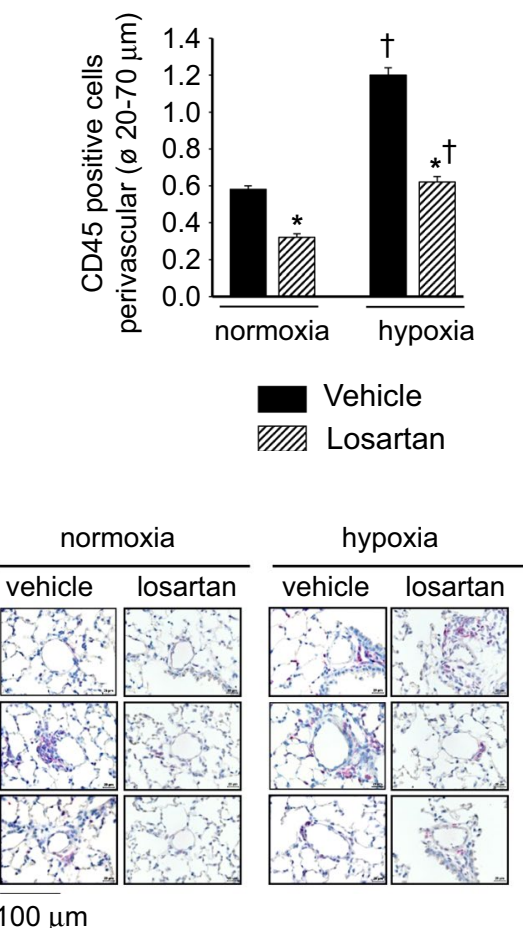

provide a link to the Creative Commons licence, and indicate if changes were made. The images or other third party material in this article are included in the article's Creative Commons licence, unless indicated otherwise in a credit line to the material. If material is not included in the article's Creative Commons licence and your intended use is not permitted by statutory regulation or exceeds the permitted use, you will need to obtain permission directly from the copyright holder. To view a copy of this licence, visit http://creativecommons.org/licenses/by/4.0/. 